\title{
Effective parameters for the adsorption of chromium(III) onto iron oxide magnetic nanoparticle
}

\author{
T. Shahriari · G. Nabi Bidhendi · N. Mehrdadi • \\ A. Torabian
}

Received: 17 March 2013/Revised: 24 April 2013/Accepted: 27 April 2013/Published online: 17 May 2013

(C) Islamic Azad University (IAU) 2013

\begin{abstract}
Most of the industrial wastewaters comprise toxic, biologically non-biodegradable, and heavy metals which tend to accumulate in the biological organisms causing different diseases. There are some novel technologies and strategies to remove these pollutants. Using the magnetic nanoparticles which are cheap, recyclable, and reusable can be considered as an effective method for removing the pollutants as they do not require conservation or complicated equipments. Using this method, dangerous and rare heavy metals can be restored to the industry. In this study, magnetic nanoparticles with the size of $30 \mathrm{~nm}$ were prepared and used for the removal of chromium from synthetic wastewater polluted by chromium sulfate. For this purpose, removal of various concentrations of chromium(III) from wastewater was investigated. The best concentration was achieved in the removal efficiency of $99.1 \%$. The optimal values of $\mathrm{pH}$, rotation speed of magnetic stirrer, time, temperature, and the amount of nanoparticles were determined according to the primary concentration $(500 \mathrm{mg} / \mathrm{L})$. The mechanism of chromium adsorption onto iron oxide $\left(\mathrm{Fe}_{3} \mathrm{O}_{4}\right)$ magnetic nanoadsorbent was also investigated. The results showed both Freundlich and Longmuir isotherms to be the best fit for the chromium adsorption, with Freundlich isotherm being more suitable.
\end{abstract}

T. Shahriari $(\bowtie) \cdot$ G. Nabi Bidhendi $\cdot$ N. Mehrdadi

A. Torabian

Faculty of Environment, University of Tehran, Tehran, Iran

e-mail: shahriari1353@yahoo.com

Present Address:

T. Shahriari

No. 25, Azin Ave., Qods Street, Enghelab Street, Tehran, Iran
Keywords Chromium removal $\cdot$ Equilibrium time . Nanoadsorbent $\cdot \mathrm{pH} \cdot$ Tannery wastewater

\section{Introduction}

In recent decades, the environment exposure to heavy metals has triggered worldwide concerns, resulting in utilizing a host of treatment techniques and processes (Shen et al. 2009). One of these techniques is the process of electrocoagulation which is a novel and efficient method for heavy metals removal (Akbal and Camc 2011; Arroyo et al. 2009; Bhatti et al. 2009; Schulz et al. 2009; Sun et al. 2009). Other methods for removing metal ions from wastewater are deposition, evaporation, solvent extraction, ion exchange, reverse osmosis, separation by membrane, etc. Most of these methods have some shortcomings such as high cost of operation, high required investment, and disposal of metal sludge; therefore, attempts have been made to develop cheap materials for removing pollutants from aquatic environments (Dizadji and Abootalebi Anaraki 2011; Malakootian et al. 2009; Shen et al. 2009). The new advancements in using nanoparticles have solved some of the problems in this regard (Ambashta and Sillanpää 2010).

Having appropriate adsorption surfaces, nanoparticles enjoy unique characteristics (Faraji et al. 2010; Xu et al. 2012). Metal nano-oxides were also applied to remove heavy metals from water and wastewater (Hua et al. 2012); for instance, iron oxide $\left(\mathrm{Fe}_{3} \mathrm{O}_{4}\right)$ magnetic nanoparticle is efficient not only in the adsorption of metals, but also in medical (Shen et al. 2009) and biotechnological processes (Yavuz et al. 2009). Another advantage of magnetic nanoparticles is that they can be easily separated from liquid via external magnetic field (Shen et al. 2009). In 
comparison with common treatment methods, utilization of magnetic nanoparticles brings about many advantages, such as requiring simple equipments, facilitated operation, high efficiency, and high potentials for restoration and reusability of magnetic beds, which have made them well qualified to be widely applied. They can be used not only in the treatment of wastewater contaminated with heavy metals, but also in major industries owing to their reusability and metal recyclability (Chen et al. 2011).

Many studies have been carried out showing the high efficiency of magnetic nanoparticles in removing different pollutants, especially heavy metals, from water and wastewater, including oil refinery wastewater treatment using zero-valent iron nanoparticles by ultrasound (Rasheed et al. 2011); paper mill wastewater treatment by iron oxide covered with polyacrylic acid for the purpose of chemical oxygen demand (COD) removal (Zhang et al. 2011); application of $\mathrm{Fe}_{3} \mathrm{O}_{4}$ magnetic nanoparticles for color removal from water (Absalan et al. 2011; Iram et al. 2010); methylene blue removal from aquatic environment by $\mathrm{Fe}_{3} \mathrm{O}_{4}$ nanoparticles fixed with pectin (Rakhshaee and Panahandeh 2011); reduction of polybrominated diphenyl ethers (PBDE) by metal nanoparticles (Fang et al. 2011a); adsorption of cadmium from aquatic environment by magnetic nanoparticles and its restoration from industrial wastewater by magnetic particles (Chen et al. 2011; Tu et al. 2012); copper and chromium(VI) adsorption from aquatic environment by iron oxide magnetic nanoparticles with amino factor groups (Shen et al. 2012); chromium(VI) removal from electroplating wastewater by metal nanoparticles (Fang et al. 2011b); iron nanoparticles fixed with pectin to remove color from aquatic solution (Rakhshaee 2011); reduction of decabromodiphenyl ether by zero-valent iron nanoparticles fixed within mesoporous of silica microspheres (Qiu et al. 2011); adsorption of arsenite onto the $\mathrm{Fe}_{2} \mathrm{O}_{3}$ nanoparticles and arsenic removal from water by $\mathrm{Fe}_{3} \mathrm{O}_{4}$ nanoparticles (Akin et al. 2012; Prasad et al. 2011); application of $\mathrm{Fe}_{3} \mathrm{O}_{4}$ magnetic nanoparticles with functional groups of carboxyl, amine, and thiol in removing Escherichia coli and toxic metals ions (Singh et al. 2011); using bakery yeast along with $\mathrm{Fe}_{3} \mathrm{O}_{4}$ nanoparticles to remove methyl violet from aquatic environment (Tian et al. 2010); lead removal from aqueous solution by magnetic nanoparticles (Tan et al. 2012); removal of heavy metal ions from aquatic environment using $\mathrm{Fe}_{3} \mathrm{O}_{4}$ magnetic nanoparticles reformed by polymer (Ge et al. 2012); removing ions of nickel, cadmium, and lead from water by $\mathrm{Fe}_{3} \mathrm{O}_{4}$ nanoparticles reformed by carboxymethyl- $\beta$-cyclodextrin (Badruddoza et al. 2013); treatment of wastewater by $\mathrm{Fe}_{3} \mathrm{O}_{4}$ nanoparticles (Shen et al. 2009); and $\mathrm{Pb}(\mathrm{II})$ removal from wastewater by magnetic nanoparticles of iron oxide (Nassar 2010).
Chromium is a transition element of VI B periodic table. Chromium sulfate can be mentioned as one of the most important and common chromic compounds (Mortimer 1986).

Investigations imply that chromium(III) removal by $\mathrm{Fe}_{3} \mathrm{O}_{4}$ magnetic nanoparticles yet has not been carried out. The present study is an attempt to investigate the performance of $\mathrm{Fe}_{3} \mathrm{O}_{4}$ magnetic nanoparticles in removing chromium(III) as a pollutant with various concentrations. The role of effective parameters including $\mathrm{pH}$, temperature, rotation speed of magnetic stirrer, amount of nanoparticles, and contact time has also been considered. This study was carried out in water and wastewater treatment laboratory at Tehran University on 2012.

\section{Materials and methods}

For the purpose of removing chromium pollution, artificial wastewater containing chromium(III) ions with the initial concentrations of $250,500,750$, and $1,000 \mathrm{mg} / \mathrm{L}$ was tested separately. The reason for choosing these concentrations is the variability of chromium concentration in tanning wastewater from 400 to $1,700 \mathrm{mg} / \mathrm{L}$ (Ludvik 2000).

In this study, chromium sulfate $\left[\mathrm{Cr}_{2}\left(\mathrm{SO}_{4}\right)_{2}(\mathrm{OH})_{2} \cdot 16 \mathrm{H}_{2} \mathrm{O}\right]$ made by Rock Chemical Company was used. The size of $\mathrm{Fe}_{3} \mathrm{O}_{4}$ magnetic nanoparticle used in this study was $30 \mathrm{~nm}$, which is considered an average particle size. The nanopowder was of $99 \%$ purity, with specific surface of $55 \mathrm{~m}^{2} / \mathrm{g}$.

To prepare nanoparticles, the mixture of $\mathrm{FeCl}_{2}$ and propylene glycol was boiled. Thereafter, sodium hydroxide $(\mathrm{NaOH})$ was gradually added to the mixture until $\mathrm{pH}$ was raised. The mixture was then stirred and cooled to reach the room temperature, and $\mathrm{Fe}_{3} \mathrm{O}_{4}$ particles were separated by centrifugal movement. The obtained particles were characterized using a transition electron microscope. The test was conducted under the conditions that optimal time of the experiment and optimal rotation speed of magnetic stirrer were $45 \mathrm{~min}$ and $200 \mathrm{rpm}$, respectively. Before conducting the test and after carrying out the experiment, the concentration of chromium(III) was determined in the samples according to the standard methods of water and wastewater experiments (Franson 2005). The concentration of chromium was determined by atomic absorption spectrophotometry. IKA magnetic stirrer with RCT Basic (made in Germany) and Metrohm $691 \mathrm{pH}$ meter (made in Switzerland) were used. The wastewater obtained from chromium sulfate was touched by $\mathrm{Fe}_{3} \mathrm{O}_{4}$ magnetic nanoparticles. After the experiment, the required wastewater was immediately collected and its chromium concentration was measured accordingly. The adsorbent comprising pollutant was separated by an external magnetic field which was a horseshoe-shaped magnet. The particles were washed by sulfuric acid, and chromium(III) 
was put in the recyclable liquid. Figure 1 shows the different stages of the test. For the purpose of neutralization, magnetic nanoparticles were reduced by sodium hydroxide and washed by distilled water.

Considering the amount of $\mathrm{pH}$ discharge into the environment and in order to determine the optimal $\mathrm{pH}$, it was decided to set the value of $\mathrm{pH}$ within the range of 3-9. This was adjusted by sulfuric acid and sodium hydroxide.

\section{Results and discussion}

In this method, wastewater was touched by nanoadsorbent, the surface of which was to adsorb the pollutants. This way, the pollutant was removed from the environment and adsorbed by the adsorbent. Adsorption time, pollutant's concentration, amount of nanoparticles, and $\mathrm{pH}$ proved to be the important parameters in pollutant removal. The results of adsorption test and the percentages of chromium removal with the initial concentration of $500 \mathrm{mg} / \mathrm{L}$ in different $\mathrm{pH}$ values are shown in Fig. 2.

To determine the optimal $\mathrm{pH}$, test temperature was $25^{\circ} \mathrm{C}$, magnet rotation speed was $300 \mathrm{rpm}$, test time was $60 \mathrm{~min}$, and amount of nanoparticle was $1 \mathrm{~g}$.

Table 1 shows the amount of initial $\mathrm{pH}$ as well as final $\mathrm{pH}$ versus the amount of chromium removal after adsorption of the pollutant onto the $\mathrm{Fe}_{3} \mathrm{O}_{4}$ magnetic nanoparticles.

As Table 1 indicates, adsorption of chromium(III) occurs in the high $\mathrm{pH}$. This attributes to the fact that in high $\mathrm{pH}$, hydroxide ions are adsorbed onto the adsorbent surface, resulting in electrostatic attraction between the ions of hydroxide and chromium. In case of $\mathrm{pH}$ reduction, hydroxide surface weakens and reduces the adsorption of chromium ions. Chromium adsorption onto $\mathrm{Fe}_{3} \mathrm{O}_{4}$ occurs in a $\mathrm{pH}$ of approximately 6 . Results showed that in higher $\mathrm{pH}$, the main cause of chromium removal is the formation of hydroxide deposit. Studies carried out by Nassar (2010) confirm the obtained results as well.

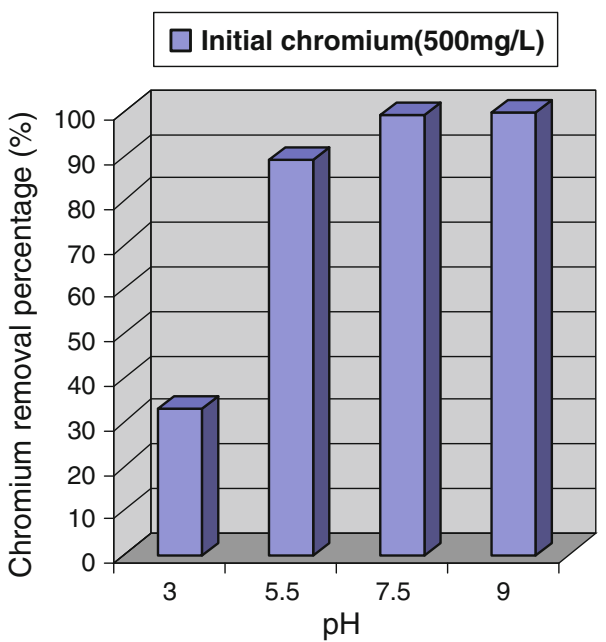

Fig. 2 Comparison of chromium removal percentages in different $\mathrm{pH}$ values after adsorption process

Table 1 Amount of initial and final chromium concentrations and $\mathrm{pH}$ values before and after adsorption process

\begin{tabular}{lcll}
\hline $\begin{array}{l}\text { Initial chromium } \\
(\mathrm{mg} / \mathrm{L})\end{array}$ & $\begin{array}{l}\text { Final chromium } \\
(\mathrm{mg} / \mathrm{L})\end{array}$ & Initial $\mathrm{pH}$ & Final $\mathrm{pH}$ \\
\hline 500 & 336.42 & 3 & 2.99 \\
500 & 55.05 & 5.5 & 5.13 \\
500 & 3.95 & 7.5 & 6.41 \\
500 & 0.6 & 9 & 6.95 \\
\hline
\end{tabular}

The factors investigated in this study are amount of iron oxide nanoparticles, optimal time of the test, magnet rotation speed, and the test temperature in the initial chromium concentration of $500 \mathrm{mg} / \mathrm{L}$. The impact of initial concentration of chromium on the amount of adsorption was studied as well. The analysis of these factors has been given further in the present study. To obtain the amount of nanoparticles, the tests were carried out using $0.25,0.5$, $0.75,1$, and $1.5 \mathrm{~g}$ of $\mathrm{Fe}_{3} \mathrm{O}_{4}$ magnetic nanoparticles, with the $\mathrm{pH}$ of 5.5. The obtained results have been indicated in

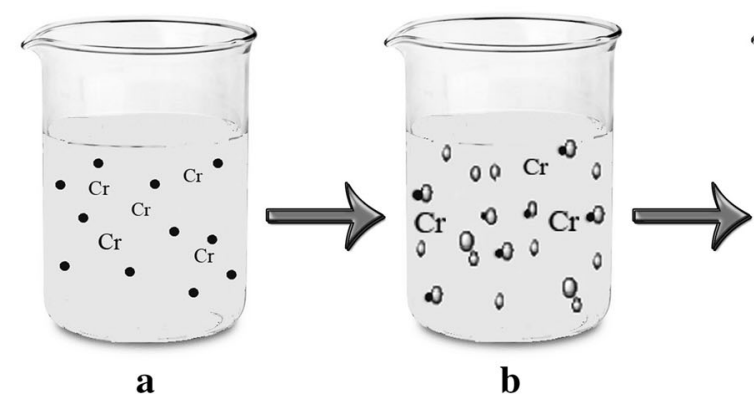

Fig. 1 Stages of chromium removal from wastewater by $\mathrm{Fe}_{3} \mathrm{O}_{4}$ nanoparticles, and its separation and reduction. a Wastewater comprising chromium(III); b encompassing chromium(III) by magnetic

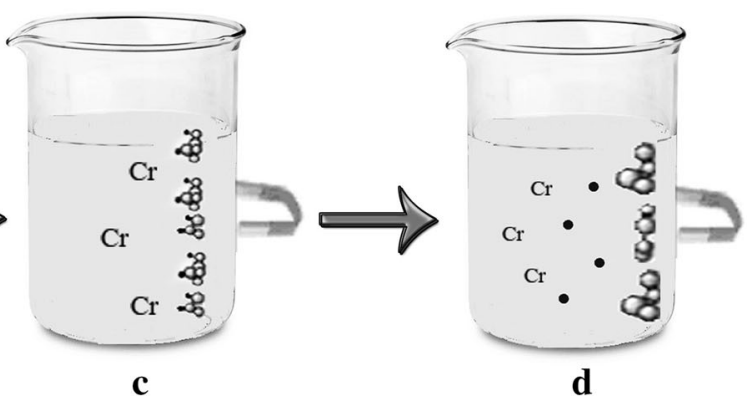

nanoparticles; c chromium(III) removal by magnetic separation; d reduction of chromium(III); and reuse of magnetic nanoparticles 


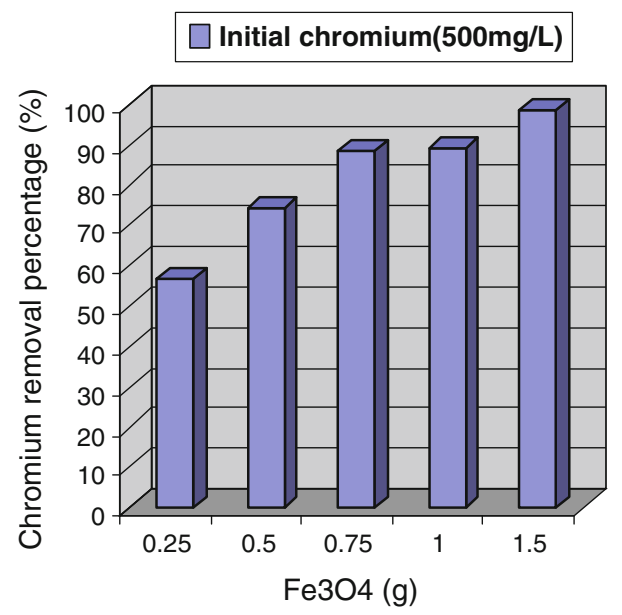

Fig. 3 Comparison of chromium removal percentages with different amounts of $\mathrm{Fe}_{3} \mathrm{O}_{4}$ nanoparticles after adsorption process

Table 2 Initial and final chromium and $\mathrm{pH}$ before and after adsorption process with different amounts of nanoparticles

\begin{tabular}{lllll}
\hline $\begin{array}{l}\text { Amount of } \\
\text { nanoparticle }(\mathrm{g})\end{array}$ & $\begin{array}{l}\text { Initial } \\
\text { chromium } \\
(\mathrm{mg} / \mathrm{L})\end{array}$ & $\begin{array}{l}\text { Final } \\
\text { chromium } \\
(\mathrm{mg} / \mathrm{L})\end{array}$ & $\begin{array}{l}\text { Initial } \\
\mathrm{pH}\end{array}$ & $\begin{array}{l}\text { Final } \\
\mathrm{pH}\end{array}$ \\
\hline 0.25 & 500 & 215.44 & 5.46 & 4.47 \\
0.5 & 500 & 128.46 & 5.64 & 4.53 \\
0.75 & 500 & 58.6 & 5.58 & 4.48 \\
1 & 500 & 55.05 & 5.75 & 4.60 \\
1.5 & 500 & 7.64 & 5.69 & 4.71 \\
\hline
\end{tabular}

Fig. 3 and Table 2. As it can be seen, higher amount of nanoparticles leads to higher removal percentage. The results of adsorption using 0.75 and $1 \mathrm{~g}$ of nanoparticles were found to be almost the same. Therefore, to obtain the optimal values of other parameters, the experiments went on using $0.75 \mathrm{~g}$ of nanoparticles. With an increase in the amount of nanoparticles, adsorption rate was increased due to the increase in adsorption sites. Previous studies have also highlighted this point (Nassar 2010; Shen et al. 2009).

To obtain optimal time, the tests were carried out in various time durations of $15,25,30,45,60$, and $90 \mathrm{~min}$. The obtained results have been given in Fig. 4 and Table 3 . As can be seen, the optimal time was considered to be $45 \mathrm{~min}$ and an increase in the test time increased the removal percentage. The increase was so extensive that the adsorbent surfaces become saturated. Afterward, no adsorption increase was observed. In these experiments, the amount of nanoparticles was $0.75 \mathrm{~g}$, the temperature was $25^{\circ} \mathrm{C}$, magnet rotation speed was $300 \mathrm{rpm}$, and the initial $\mathrm{pH}$ was 5.5. The equilibrium time obtained in this study revealed to be consistent with that obtained in the studies carried out by Nassar (2010).

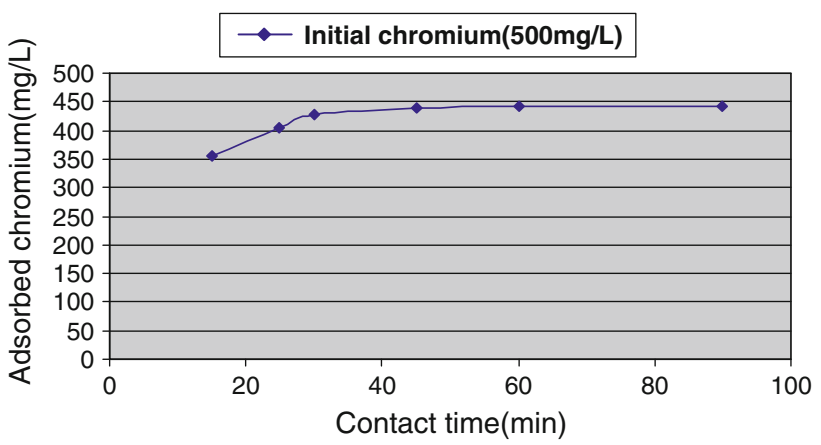

Fig. 4 Comparison of the final adsorbed chromium in various test time durations after adsorption process

Table 3 Comparison of initial and final chromium after adsorption process in different time durations

\begin{tabular}{lll}
\hline Time of test $(\mathrm{min})$ & $\begin{array}{l}\text { Initial chromium } \\
(\mathrm{mg} / \mathrm{L})\end{array}$ & $\begin{array}{l}\text { Final chromium } \\
(\mathrm{mg} / \mathrm{L})\end{array}$ \\
\hline 15 & 500 & 144.05 \\
25 & 500 & 95.8 \\
30 & 500 & 73.69 \\
45 & 500 & 60.76 \\
60 & 500 & 58.6 \\
90 & 500 & 56.46 \\
\hline
\end{tabular}

To determine the appropriate magnet rotation speed, the tests were carried out using $0.75 \mathrm{~g}$ of nanoparticles, at the temperature of $25{ }^{\circ} \mathrm{C}$, the test time of $45 \mathrm{~min}$, and initial $\mathrm{pH}$ of 5.5. The appropriate rotation speed was $200 \mathrm{rpm}$ (Fig. 5). The amount of $\mathrm{pH}$ in Table 4 indicates that after the adsorption of hydroxide ions by nanoparticles, chromium was adsorbed onto the particles. This mechanism plays an important role in the process of removing the pollutants. Therefore, higher rotation speed would break the bonds and release the pollutants which lead to a decrease in chromium removal efficiency.

To determine the optimal temperature of the test and the effect of temperature on adsorption process during the chromium removal, several experiments were carried out in different temperatures of $15,20,25$, and $30^{\circ} \mathrm{C}$. In the series of experiments, test duration was $45 \mathrm{~min}$ with $200 \mathrm{rpm}$ rotation speed and $0.75 \mathrm{~g}$ of nanoparticles with the initial $\mathrm{pH}$ of 5.5 was used. The amount of chromium removal was affected by the initial temperature shown in Fig. 6.

As Table 5 shows, the existing reactions in the adsorption process are endothermic and any increase in temperature within a special time also increases the amount of chromium removal. Since the increase in temperature led to the increase in the amount of energy consumption, the 


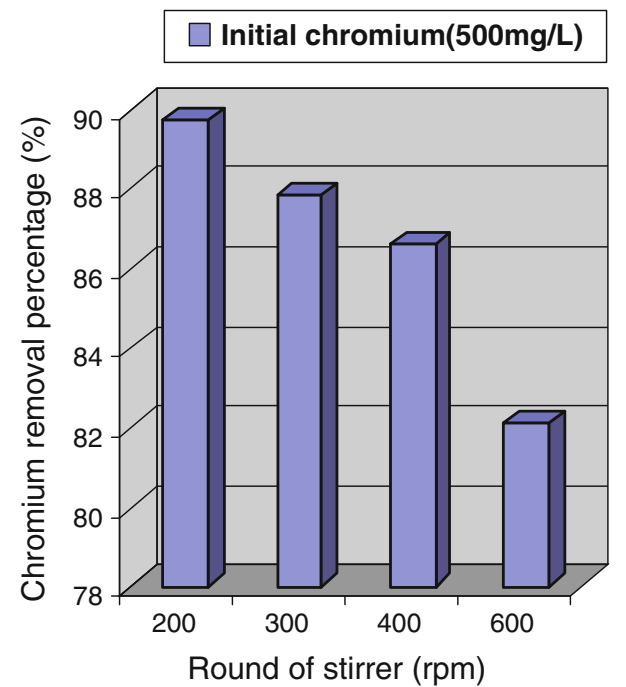

Fig. 5 Comparison of chromium removal percentages in different rotation speeds of magnetic stirrer after adsorption process

Table 4 Comparison of initial and final chromium and $\mathrm{pH}$ values after adsorption process in different rotation speeds

\begin{tabular}{lllll}
\hline $\begin{array}{l}\text { Round of } \\
\text { stirrer }(\mathrm{mg} / \mathrm{L})\end{array}$ & $\begin{array}{l}\text { Initial } \\
\text { chromium } \\
(\mathrm{mg} / \mathrm{L})\end{array}$ & $\begin{array}{l}\text { Final } \\
\text { chromium } \\
(\mathrm{mg} / \mathrm{L})\end{array}$ & $\begin{array}{l}\text { Initial } \\
\mathrm{pH}\end{array}$ & $\begin{array}{l}\text { Final } \\
\mathrm{pH}\end{array}$ \\
\hline 200 & 500 & 51.29 & 5.53 & 4.41 \\
300 & 500 & 60.76 & 5.49 & 4.54 \\
400 & 500 & 66.93 & 5.48 & 4.56 \\
600 & 500 & 89.47 & 5.68 & 4.77 \\
\hline
\end{tabular}

optimal temperature was decided to be $25{ }^{\circ} \mathrm{C}$ in these experiments. The results achieved at 25 and $30{ }^{\circ} \mathrm{C}$ were almost the same. Researches by Shen et al. (2009) and Nassar (2010) imply that the increase in temperature increases ions mobility and more ions are therefore adsorbed onto the active sites of adsorbent. Therefore, absorption process leads to the increase in the removal efficiency of metal ions.

The results of adsorption test and percentage of chromium removal with different concentrations of chromium have been given in Table 6 and Fig. 7. Test temperature was $25{ }^{\circ} \mathrm{C}$ with magnet rotation speed of $200 \mathrm{rpm}$, and test time was 45 min with $1 \mathrm{~g}$ of nanoparticles and initial $\mathrm{pH}$ of 6 . The reason for increase in the amount of nanoparticles was an increase in the subject of test which required enough surfaces for the adsorption.

The adsorption efficiency decrease was due to an increase in concentration. Studies by Iram et al. (2010) show that the increase in concentration leads to the decrease in removal efficiency.

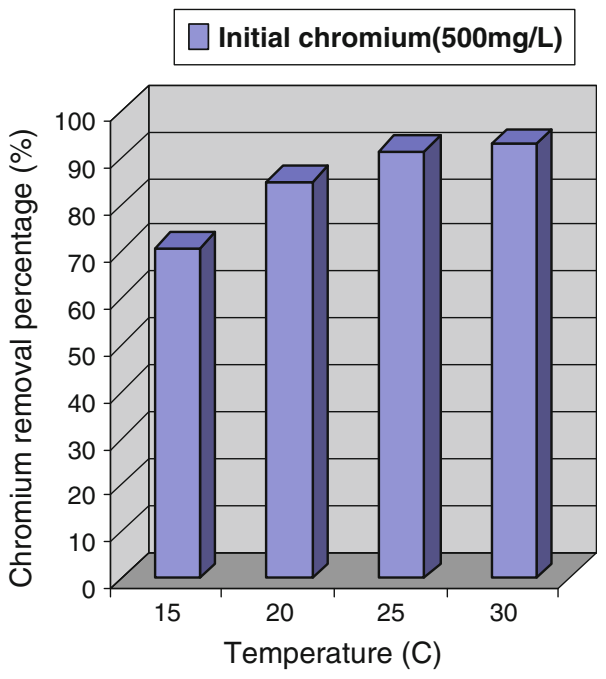

Fig. 6 Comparison of chromium removal percentages in different temperatures after adsorption process using $\mathrm{Fe}_{3} \mathrm{O}_{4}$ magnetic nanoparticles

Table 5 Initial and final chromium and $\mathrm{pH}$ values in different temperatures before and after adsorption process

\begin{tabular}{lllll}
\hline $\begin{array}{l}\text { Initial } \\
\text { temperature } \\
\left({ }^{\circ} \mathrm{C}\right)\end{array}$ & $\begin{array}{l}\text { Initial } \\
\text { chromium } \\
\mathrm{L})\end{array}$ & $\begin{array}{l}\text { Final } \\
\text { chromium }(\mathrm{mg} / \\
\mathrm{L})\end{array}$ & $\begin{array}{l}\text { Initial } \\
\mathrm{pH}\end{array}$ & $\begin{array}{l}\text { Final } \\
\mathrm{pH}\end{array}$ \\
\hline 15 & 500 & 146.32 & 5.70 & 4.67 \\
20 & 500 & 74.87 & 5.71 & 4.62 \\
25 & 500 & 43.23 & 5.59 & 4.48 \\
30 & 500 & 35.55 & 5.63 & 4.46 \\
\hline
\end{tabular}

Table 6 Comparison of initial and final chromium and its removal percentages after adsorption process in different initial concentrations

\begin{tabular}{lcl}
\hline Initial chromium $(\mathrm{mg} / \mathrm{L})$ & Final chromium $(\mathrm{mg} / \mathrm{L})$ & Removal \% \\
\hline 1,000 & 30.37 & 96.96 \\
750 & 16.83 & 97.76 \\
500 & 9.6 & 98.08 \\
250 & 2.25 & 99.1 \\
\hline
\end{tabular}

To investigate the mechanism of adsorption of trivalent chromium ion by $\mathrm{Fe}_{3} \mathrm{O}_{4}$ magnetic nanoparticle, Langmuir and Freundlich isotherm constants were adjusted with the data. Using Langmuir and Freundlich isotherms, the ability and capacity of the adsorbent were determined. Langmuir isotherm is based on single-layer adsorption and lack of movement of adsorbed material, and Langmuir model describes the adsorption occurring on homogeneous 


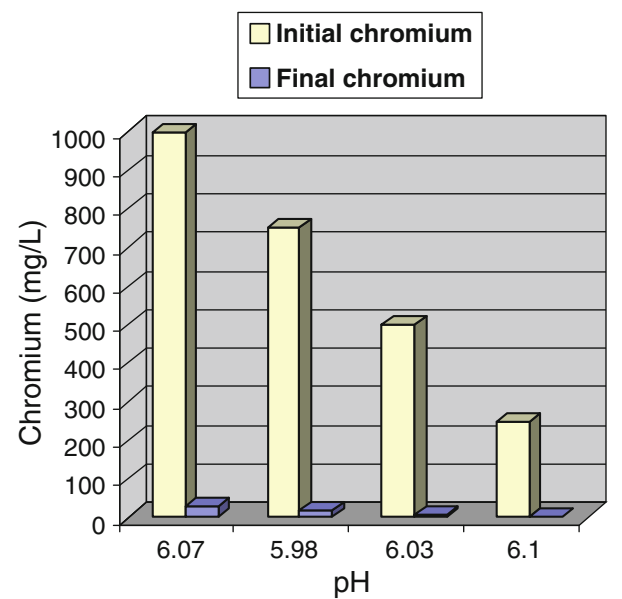

Fig. 7 Comparison of initial and final chromium with different concentrations throughout the adsorption process

surfaces. Linear form of Langmuir equation for adsorption is as follows:

$\frac{C_{e}}{q_{e}}=\frac{1}{b \cdot q_{m}}+\frac{C_{e}}{q_{m}}$

Drawing $C_{e} / q_{e}$ versus $C_{e}$, a straight line can be obtained, where $q_{e}(\mathrm{mg} / \mathrm{g})$ is absorption capacity, $C_{e}(\mathrm{mg} / \mathrm{L})$ is equilibrium adsorbate concentration, $q_{m}$ is maximum value of $q_{e}$ with increasing $C_{e}$, and $b$ is a coefficient associated with adsorption energy and related to adsorption bond strength.

Freundlich model describes the adsorption occurring on adsorbent heterogeneous surfaces. Freundlich equation is as follows:

$\log q_{e}=\log K+\frac{1}{n} \log C_{e}$

where $q_{e}$ is the amount of adsorbate per unit of adsorbent at equilibrium condition $(\mathrm{mg} / \mathrm{g}), C_{e}$ is equilibrium

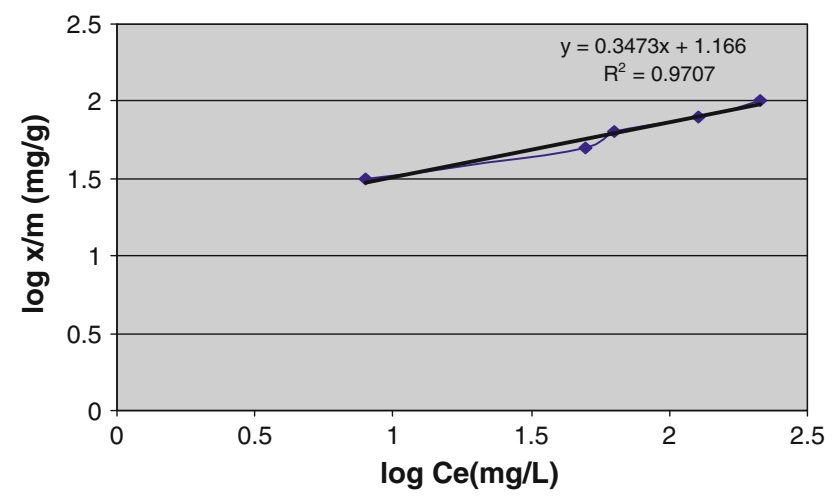

Fig. 8 Freundlich isotherm of $\mathrm{Cr}(\mathrm{III})$ adsorption onto $\mathrm{Fe}_{3} \mathrm{O}_{4}$ magnetic nanoparticles

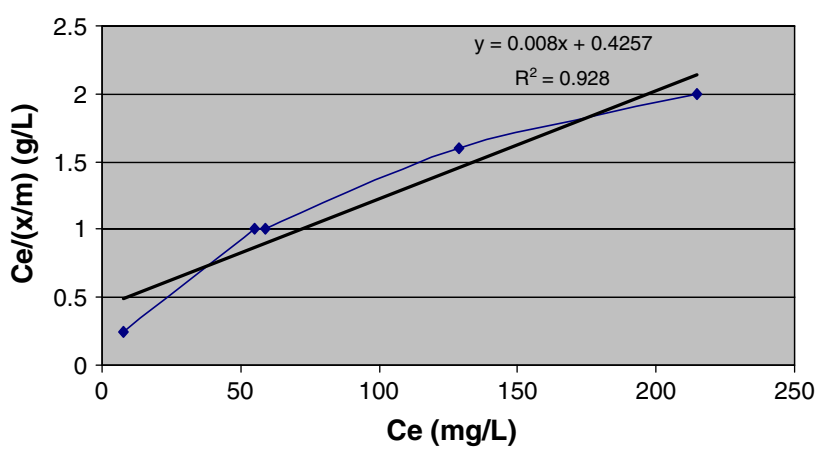

Fig. 9 Langmuir isotherm of $\mathrm{Cr}(\mathrm{III})$ adsorption onto $\mathrm{Fe}_{3} \mathrm{O}_{4}$ magnetic nanoparticles

concentration in solution $(\mathrm{mg} / \mathrm{L})$, and $K$ and $n$ are Freundlich constants (Absalan et al. 2011; Nassar 2010). Adsorption isotherms were determined at the temperatures of $25^{\circ} \mathrm{C}$.

As it is evident, Langmuir and Freundlich isotherm models can be taken as good models for the adsorption of chromium onto $\mathrm{Fe}_{3} \mathrm{O}_{4}$ magnetic nanoparticles. According to Figs. 8 and 9 , the amount of $R^{2}$ proves that Freundlich isotherm is a more suitable model for adsorbing chromium onto the nanoparticles.

\section{Conclusion}

The existing pollutant in the environment was touched by nanoparticles with suitable adsorption surfaces. In this way, the pollutant was removed from the environment and adsorbed by the adsorbent. Thereafter, magnetic adsorbent and the pollutant were separated from the liquid by an external magnetic field in order to be prepared for the further adsorption. The mechanism of chromium(III) removal by adsorption process is affected by $\mathrm{pH}$. In this study, the optimal $\mathrm{pH}$ was about 6 and hydroxide was adsorbed by the adsorbent. Afterward, electrostatic attraction occurred between hydroxide and chromium ions within the wastewater. In higher $\mathrm{pH}$ values, the existence of hydroxide induced the formation of metal hydroxide deposit. The reactions in this process were endothermic; thereby, higher temperature was suitable for the chromium removal. On the other hand, higher temperature would lead to higher energy consumption. Considering the results from the experiments, the optimal temperature of $25^{\circ} \mathrm{C}$ was suggested. The longer the test time, the higher amount of pollutant was adsorbed by active levels of the adsorbent. Thus, the adsorbing levels were rapidly saturated which was due to the fact that an increase in time duration of the test would have no effect on the process of adsorption. The results obtained from the test prove that Freundlich 
isotherm is a more suitable model for chromium adsorption onto nanoparticles. The results showed that test time reduced by increase in the amount of nanoparticles, temperature, and $\mathrm{pH}$; however, to determine each parameter, the environmental and economical issues must be closely taken into account.

Acknowledgments The authors wish to acknowledge the CEO and all authorities of Rock Chemical Company, Tehran, Iran, for supporting this study.

\section{References}

Absalan G, Asadi M, Kamran S, Sheikhian L, Goltz D (2011) Removal of reactive red-120 and 4-(2-pyridylazo) resorcinol from aqueous samples by $\mathrm{Fe}_{3} \mathrm{O}_{4}$ magnetic nanoparticles using ionic liquid as modifier. J Hazard Mater 192(2):476-484

Akbal F, Camc S (2011) Copper, chromium and nickel removal from metal plating wastewater by electrocoagulation. Desalination 269:214-222

Akin I, Arslan G, Tor A, Ersoz M, Cengeloglu Y (2012) Arsenic $(\mathrm{V})$ removal from underground water by magnetic nanoparticles synthesized from waste red mud. J Hazard Mater 235-236:62-68

Ambashta R, Sillanpää M (2010) Water purification using magnetic assistance: a review. J Hazard Mater 180(1-3):38-49

Arroyo MG, Perez-Herranz V, Montanes MT, García-Anton J, Guinon JL (2009) Effect of pH and chloride concentration on the removal of hexavalent chromium in a batch electrocoagulation reactor. J Hazard Mater 169:1127-1133

Badruddoza AZM, Shawon ZBZ, Daniel Tay WJ, Hidajat K, Shahab Uddin $\mathrm{M}$ (2013) $\mathrm{Fe}_{3} \mathrm{O}_{4}$ /cyclodextrin polymer nanocomposites for selective heavy metals removal from industrial wastewater. Carbohydrates 91(1):322-332

Bhatti M, Reddy A, Thukral A (2009) Electrocoagulation removal of $\mathrm{Cr}(\mathrm{VI})$ from simulated wastewater using response surface methodology. J Hazard Mater 172:839-846

Chen Y, Qian H, Wu F, Zhou J (2011) Clearance and recovery of $\mathrm{Cd}(\mathrm{II})$ from aqueous solution by magnetic separation technology. Chemosphere 83:1214-1219

Dizadji N, Abootalebi Anaraki N (2011) Adsorption of chromium and copper in aqueous solutions using tea residue. Int J Environ Sci Tech 8(3):631-638

Fang Z, Qiu X, Chen J, Qiu X (2011a) Degradation of the polybrominated diphenyl ethers by nanoscale zero-valent metallic particles prepared from steel pickling waste liquor. Desalination 267(1):34-41

Fang Z, Qiu X, Huang R, Qiu X, Li M (2011b) Removal of chromium in electroplating wastewater by nanoscale zero-valent metal with synergistic effect of reduction and immobilization. Desalination 280(1-3):224-231

Faraji M, Yamini Y, Rezaee M (2010) Magnetic nanoparticles: synthesis, stabilization, functionalization, characterization. J Iran Chem Soc 7(1):1-37

Franson MA (2005) Standard methods for the examination of water and wastewater, 21st edn. American Public Health Association, USA

Ge F, Li M, Ye H, Zhao B (2012) Effective removal of heavymetal ions $\mathrm{Cd}^{2+}, \mathrm{Zn}^{2+}, \mathrm{Pb}^{2+}, \mathrm{Cu}^{2+}$ from aqueous solution by polymermodified magnetic nanoparticles. J Hazard Mater 211-212: 366-372
Hua M, Zhang Sh, Pan B, Zhang W, Lv L, Zhang Q (2012) Heavy metal removal from water/wastewater by nanosized metal oxides: a review. J Hazard Mater 211-212:317-331

Iram M, Guo Ch, Guan Y, Ishfaq A, Liu H (2010) Adsorption and magnetic removal of neutral red dye from aqueous solution using $\mathrm{Fe}_{3} \mathrm{O}_{4}$ hollow nanospheres. J Hazard Mater 181:1039-1050

Ludvik J (2000) Regional programme for pollution control in the tanning industry in South-East Asia, the scope for decreasing pollution load in leather processing. United Nations Industrial Development Organization

Malakootian M, Nouri J, Hossaini H (2009) Removal of heavy metals from paint industry's wastewater using Leca as an available adsorbent. Int J Environ Sci Tech 6(2):183-190

Mortimer Ch (1986) General chemistry, metals and metallurgy, transition metal, 6th edn. Wadsworth, Belmont

Nassar NN (2010) Rapid removal and recovery of $\mathrm{Pb}(\mathrm{II})$ from wastewater by magnetic nanoadsorbents. J Hazard Mater 184:538-546

Prasad B, Ghosh C, Chakraborty A, Bandyopadhyay N, Ray RK (2011) Adsorption of arsenite $\left(\mathrm{As}^{3+}\right)$ on nano-sized $\mathrm{Fe}_{2} \mathrm{O}_{3}$ waste powder from the steel industry. Desalination 274(1-3): $105-112$

Qiu X, Fang Z, Liang B, Gu F, Xu Z (2011) Degradation of decabromodiphenyl ether by nano zero-valent iron immobilized in mesoporous silica microspheres. J Hazard Mater 193:70-81

Rakhshaee R (2011) Rule of Fe nano-particles and biopolymer structures in kinds of the connected pairs to remove Acid Yellow 17 from aqueous solution: simultaneous removal of dye in two paths and by four mechanisms. J Hazard Mater 197:144-152

Rakhshaee R, Panahandeh M (2011) Stabilization of a magnetic nanoadsorbent by extracted pectin to remove methylene blue from aqueous solution: a comparative studying between two kinds of cross-likened pectin. J Hazard Mater 189:158-166

Rasheed QJ, Pandian K, Muthukumar K (2011) Treatment of petroleum refinery wastewater by ultrasound-dispersed nanoscale zero-valent iron particles. Ultrason Sonochem 18(5): $1138-1142$

Schulz MC, Baygents JC, Farrell J (2009) Laboratory and pilot testing of electrocoagulation for removing scale-forming species from industrial process waters. Int J Environ Sci Tech 6(4):521-526

Shen YF, Tang J, Nie ZH, Wang YD, Ren Y, Zuo L (2009) Preparation and application of magnetic $\mathrm{Fe}_{3} \mathrm{O}_{4}$ nanoparticles for wastewater purification. Sep Purif Technol 68:312-319

Shen H, Pan Sh, Zhang Y, Huang X, Gong H (2012) A new insight on the adsorption mechanism of amino-functionalized nano- $\mathrm{Fe}_{3} \mathrm{O}_{4}$ magnetic polymers in $\mathrm{Cu}(\mathrm{II}), \mathrm{Cr}(\mathrm{VI})$ co-existing water system. Chem Eng J 183:180-191

Singh S, Barick KC, Bahadur D (2011) Surface engineered magnetic nanoparticles for removal of toxic metal ions and bacterial pathogens. J Hazard Mater 192(3):1539-1547

Sun L, Miznikov E, Wang L, Adin A (2009) Nickel removal from wastewater by electroflocculation-filtration hybridization. Desalination 249:832-836

Tan Y, Chen M, Hao Y (2012) High efficient removal of Pb(II) by amino-functionalized $\mathrm{Fe}_{3} \mathrm{O}_{4}$ magnetic nano-particles. Chem Eng J 191:104-111

Tian Y, Ji C, Zhao M, Xu M, Zhang Y, Wang R (2010) Preparation and characterization of baker's yeast modified by nano- $\mathrm{Fe}_{3} \mathrm{O}_{4}$ : application of biosorption of methyl violet in aqueous solution. Chem Eng J 165(2):474-481

Tu Y, You C, Chang C (2012) Kinetics and thermodynamics of adsorption for $\mathrm{Cd}$ on green manufactured nano-particles. J Hazard Mater 235-236:116-122 
Xu P, Ming Zeng G, Huang DL, Feng CL, Hu S, Hua Zhao M, Lai C, Wei Z, Huang C, Xin Xie G, Feng Liu Z (2012) Use of iron oxide nanomaterials in wastewater treatment: a review. Sci Total Environ 424:1-10

Yavuz C, Prakash A, Mayo JT, Colvin VL (2009) Magnetic separations: from steel plants to biotechnology. Chem Eng Sci 64(10):2510-2521
Zhang H, Zhao Zh, Xu X, Li L (2011) Study on industrial wastewater treatment using superconducting magnetic separation. Cryogenics 51:225-228 